\title{
How Does Policy on Accreditation Affect the Quality Improvement in Indonesian Hospitals
}

\author{
Wulan I R Sari \\ Faculty of Economics and Business, Mulawarman University, Indonesia
}

wulan.sariefeb.unmul.ac.id

\begin{abstract}
There was a new Law in 2009 [1] about hospital that is seeking to improve the quality of health services across all Indonesian hospitals. One of specific attention is mandatory aspect of accreditation process. By using accreditation process the quality of health services will be improved through such criteria and standards for hospitals that are disclosed in other government regulations (such as the Ministry of Health Decree No: $129 /$ Menkes/SK/II/2008). On the other hand, the quality improvement processes are difficult to realize. This is because hospitals have limited resources, such as medical specialists and medical equipment, to meet criteria and standards. Therefore, the objective of this study is to examine how does policy on accreditation influences to the quality improvement in Indonesian hospitals. A qualitative approach is used to explore how policy on accreditation can influence services that influence hospitals on practices and processes in the quality improvement.
\end{abstract}

Results show the four hospitals are used to dealing with the relevant institutions on health services, such as Ministry of Health and the Indonesian Committee on Hospital Accreditation (KARS). There is a strong role from the KARS in improving quality through its accreditation process. This is because the KARS has huge power to control Indonesian hospitals through credentialing and licensing of services as well. To conclude, through the accreditation process, there are many ways to improve the quality of services, such as improvement in activities, data and process of services.

Keywords — policy, accreditation, quality, improvement, process, hospitals

\section{INTRODUCTION}

The Indonesian government, in releasing the new law [2], is seeking to improve the quality of health services across all Indonesian hospitals. Through this new law, the Indonesian government is encouraging hospitals to use accreditation process to improve the quality of health services and ensure that Indonesians have greater access to health services.

In health care, appropriate access involves both the availability of facilities and the cost of care to the patient [3]. The Indonesian government is building hospitals across Indonesia so that patients can access services easily, and it is paying for health services for poor patients via a healthinsurance mechanism. In terms of ensuring higher quality, accreditation of hospitals plays a key role. This is because accreditation "is public recognition of achievement by a healthcare organization, of requirements of national healthcare standards" [4].

Furthermore, accreditation is influenced by systems of accreditation and standards-setting, and in Indonesia hospitals are allocated ratings, or grades, for health facilities [5], and are graded as being either fully or conditionally accredited. It is important for a hospital to get accreditation because it is a signal of the quality of the hospital. Being accredited means that a hospital is able to meet the standards that were set by the Indonesian Joint Commission on Hospital Accreditation (IJCHA/KARS-Komite Akreditasi Rumah Sakit) on behalf of the Ministry of Health. The hospitals that have been fully accredited make up $53.7 \%$ of all hospitals, while $2.3 \%$ have been granted conditional status and $44.0 \%$ are not yet accredited (Table 1).

TABLE 1

THE NUMBER of ACCREDITED HOSPITALS

\begin{tabular}{|l|l|r|r|}
\hline No & Accreditation Status & Amount & Percentage \\
\hline 1 & Fully accredited & 1,335 & $53.7 \%$ \\
\hline 2 & Conditionally accredited & 58 & $2.3 \%$ \\
\hline 3 & Not accredited yet & 1,095 & $44.0 \%$ \\
\hline \multicolumn{2}{|r|}{ Total } & 2,488 & $100 \%$ \\
\hline
\end{tabular}

Source: [6]

There are a number of approaches and methods to evaluate the quality of medical care, and those developed by Donabedian [3], [7]-[8] are particularly relevant to the challenge faced by the Indonesian government. His approach is to divide health care services into three components: structure, process and outcomes [7]. This is a useful 
schema because it makes clear that structures affect processes, which in turn affect outcomes [9]-[10].

These sets of relationships are set out in Fig. 1 and show the following characteristics: structure includes stable characteristics that facilitate the provision of health services, such as material resources, human resources and organizational characteristics; process is the clinical services provided to a patient which include activities in screening, diagnosis, pharmacotherapy, surgery, rehabilitation, patient education and prevention; and outcomes measures describe change attributable to health care, and encompass mortality, morbidity, functional status and pain, as well as patients' health-related knowledge, behaviours and satisfaction [3], [8].

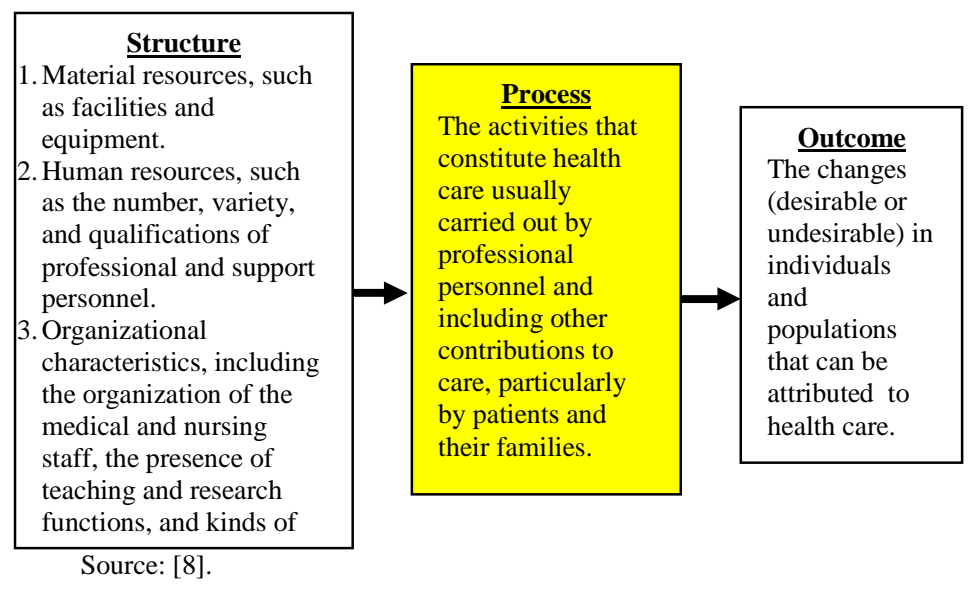

Fig. 1 Diagram of relationships between structure, process and outcome

Donabedian's framework is important because it recognizes aspects of measuring structure, process and outcome. Whereas, this study focuses only on process measuring of the quality improvement. Measuring processes provides predictors of quality rather than the outcome of health care, such as whether the time of a service meets the minimum standard time between diagnosis and service provision. Such measures are important because they show how well patient preferences match patient expectations [11]. Also, process measures can function as an early indicator system because they are the real activities performed by an organization before patient outcomes become measurable [12].

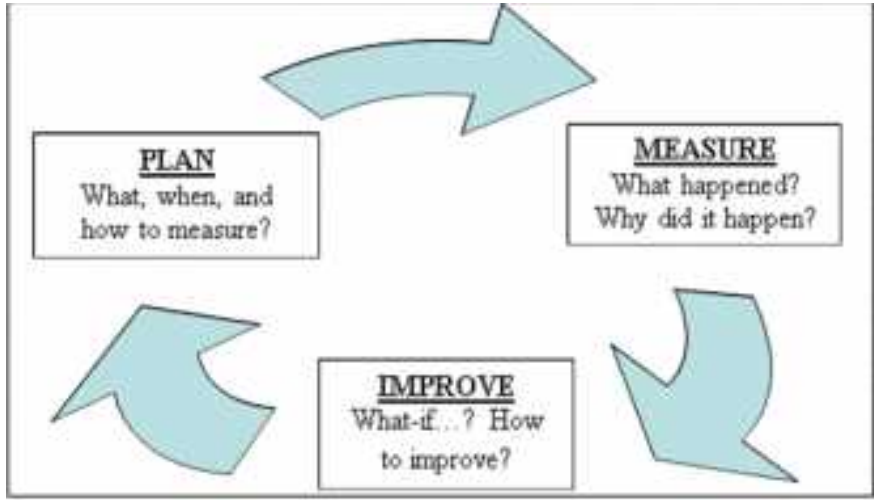

Source: [13] (as adapted).

Fig. 2 The processes of improvement

There are key activities in quality improvement processes, which are illustrated in Fig 2. They include planning, measuring and improving [13]. These activities are consistent with the plan/do/check/action (PDCA) model proposed by Deming and are related to the process of quality management [14]. The PDCA model is one of continuous quality improvement and has been widely adapted for use in performance management and the KARS as well. For example, a public hospital uses continuous quality improvement to meet patient expectations and regulation requirements (such as an accreditation process). Through accreditation processes, public hospitals are continually trying to improve the quality of health services by following their organizationwide quality strategy. In turn, accreditation processes should enable comparison of data on services and encourage the continuous process of improvement.

\section{A. Policies on Process}

The Ministry of Health, as the highest authority in the provision of quality of health care and safety of patients, is responsible for translating what patients require from a health care system into services to meet patient expectations. The Indonesian Joint Commission on Hospital Accreditation [15] established criteria to which services should be developed, measured against and ensure professional accountability. Thus, Indonesia has adopted an approach that accepts that to evaluate the quality of health care services, public hospital accreditation is needed. This is because the process 
of seeking accreditation involves measuring the level of hospital compliance in implementing and meeting all standards of services, and the commitment to comply with subsequent regulations [16]. For hospitals around the world all standards of services are developed by the Joint Commission International (JCI) Accreditation [17]. The JCI standards were developed to improve patient care and to address important health care functions. The JCI standards include a level of detail about keys health care-delivery processes, such as standards for medical staff in terms of qualifications and education.

Moreover, there are derivative lower government regulations that also give technical guidance for hospitals. For example, regulations by the Ministry of Health were established to check the quality of care. In this way the national government is encouraging hospitals to improve the quality of health services by setting criteria and standards for hospitals that are disclosed in other government regulations (such as [2]).

Furthermore, performance reporting - both financial and non financial - is another output from hospitals that needs to be done on an annual basis, but can also be done on a quarterly or semester basis for monitoring and evaluation purposes. Hospitals have to provide financial and nonfinancial documents, and to show that they have met requirements for both minimal standard of services (SPM) for all hospital services [2], and the development of the health sector [18]. To assess the quality of services, accreditation is compulsory for hospitals and has been made mandatory through the law.

Even though there are such policies supporting for quality improvement. However, the quality improvement processes are hard to do. This is because hospitals have limited human resources and facilites, such as medical specialists and medical equipment, to meet criteria and standards. As previous studies show the role of government regulations, which has a huge impact in administration, but it less impact in quality improvement processes due to lack of competent staff [19] and inconsistent results between regulatory processes and quality outcomes [20]. Therefore, the objective of this study is to analyze policy on the quality improvement process.

\section{METHODS}

A qualitative approach and a multiple case study design are used to explore how hospitals tackle specific regulations on services that influence hospitals on practices and processes in the quality improvement. Through qualitative research methods, "whereby the researcher aims to understand and interpret experiences by viewing the world through the eyes of the individuals being studied" [21]. Also, qualitative research adopts a "naturalistic approach" conducting the study in workplaces where the action takes place rather than in laboratories, and by naturalistic conversations (interviews) rather than by constrained response surveys [22]. This methods enabled the exploration of the policy on practices and processes at the four hospitals in improving services.

This study uses a multiple case study approach comparing the four hospitals. This is an extension of a single case study design [23]. These four case studies explore how specifis regulations influence practices and processes in improving quality of care, focusing on how hospitals tackle specific regulations. Cases are selected on the basis that they reflected the same class of hospitals from different provinces and different classes from the same province (Table II). This strategy was chosen because the researcher was concerned with the implementation of policies or regulations in hospitals across Indonesia. This approach uses interviews, document and policy analysis in the four hospitals and adopts a thematic approach for data analysis.

TABLE II

THE CLASSES and LOCATIONS of THE FOUR CASE STUDIES

\begin{tabular}{|l|c|c|}
\hline Class of hospital Location & Province 1 & Province 2 \\
\hline B Class hospital & Hospital P & Hospital A \\
\hline C Class hospital & Hospital W & Hospital S \\
\hline
\end{tabular}


The individuals selected for interviews were people who have, or have had, direct or indirect experience with the Indonesian hospital system. The basis of this sample selection is consequently purposive sampling [24]. Moreover, those sampled are relevant to the research questions [23]. Table III shows there are two broad groups of respondents in this study. One set of respondents has a direct relationship with health provision at the four hospitals. There were 16 staff. The other set of respondents has an indirect relationship with the four hospitals, but has an impact on the four hospitals in improving services, such as the KARS.

TABLE III

THE TYPE of INFORMATION BEING SOUGHT for EACH GROUP'S OBJECTIVES

\begin{tabular}{|c|c|c|}
\hline Group & Objectives & Questions \\
\hline 1 & $\begin{array}{l}\text { To explore policies } \\
\text { or regulations } \\
\text { influence practices } \\
\text { and processes } \\
\text { assessing quality of } \\
\text { care. }\end{array}$ & $\begin{array}{l}\text { 1. How has the process of services } \\
\text { improvements been done? } \\
\text { 2. Is accreditation helpful in improving } \\
\text { the quality of services? } \\
\text { 3. How well is your hospital able to } \\
\text { respond to demand from the } \\
\text { environment (internal and external), } \\
\text { such as the kinds of health services } \\
\text { offered and the ability to fulfil patients } \\
\text { expectations? }\end{array}$ \\
\hline 2 & $\begin{array}{l}\text { To explore policies } \\
\text { or regulations } \\
\text { influence practices } \\
\text { and processes } \\
\begin{array}{l}\text { assessing } \\
\text { care }\end{array}\end{array}$ & $\begin{array}{l}\text { 1. What is the role of regulations at your } \\
\text { hospital? How well is your hospital } \\
\text { responding to the new regulation (Law } \\
\text { No. 44/ 2009)? } \\
\text { 2. To what extent does your hospital } \\
\text { currently undertake services } \\
\text { improvement or hospital performance } \\
\text { evaluation? }\end{array}$ \\
\hline
\end{tabular}

Source: [1].

\section{RESULTS}

Government regulations or policies establish settings for hospital management and services, for governance, for performance reporting, and for quality improvement in public hospitals. Through these settings, the Indonesian government wants to encourage hospitals to focus on compliance with the standards, on better practice of administration and evaluation, and on meeting patient expectations.

There is a cronology of of accreditation processes and performance reporting in Indonesian hospitals. Table IV shows a chronolgy of the development of the different reporting that have been implemented in recent years. The overview of this experience in
Indonesia shows the gradual progress of the accreditation process and the emerging requirements for performance reporting.

TABLE IV

A CHRONOLOGY of ACCREDITATION PROCESSES and PERFORMANCE REPORTING in INDONESIAN HOSPITALS

\begin{tabular}{|l|l|l|}
\hline & \multicolumn{1}{|c|}{ Accreditation process } & \multicolumn{1}{|c|}{ Performance reporting } \\
\hline 1993 & $\begin{array}{l}\text { The Ministry of Health introduced 20 } \\
\text { standard for services in hospital. }\end{array}$ & \\
\hline 1995 & Accreditation began as a pilot project. & \\
\hline 1996 & $\begin{array}{l}\text { Accreditation was conducted } \\
\text { officially. }\end{array}$ & \\
\hline 1999 & $\begin{array}{l}\text { The number of standards for services } \\
\text { were reduced from 20 to 16. }\end{array}$ & \\
\hline 2004 & $\begin{array}{l}\text { Hospital accreditation was managed } \\
\text { and conducted by a team which is } \\
\text { functionally under the Director } \\
\text { General of Medical Care.This team, } \\
\text { IJCHA/KARS, was managed and } \\
\text { conducted by an independent working } \\
\text { unit responsible to the Ministry of } \\
\text { Health. }\end{array}$ & $\begin{array}{l}\text { General guidance for index of } \\
\text { community satisfaction at } \\
\text { services unit of government was } \\
\text { released by the Ministry of State } \\
\text { Apparatus and Bureaucracy } \\
\text { Reforms. }\end{array}$ \\
\hline 2006 & & $\begin{array}{l}\text { Each public hospital must report } \\
\text { on performanceto the } \\
\text { government. }\end{array}$ \\
\hline 2007 & & $\begin{array}{l}\text { Each public hospital can use a } \\
\text { new mechanism of financial } \\
\text { management as long as it is able } \\
\text { to fulfil requirements. The } \\
\text { requirements are a strategic } \\
\text { business plan, standards of } \\
\text { minimum service, hospital } \\
\text { governance, and financial } \\
\text { statements. }\end{array}$ \\
\hline 2009 & $\begin{array}{l}\text { Accreditation was voluntary before } \\
\text { the Law No 44/2009 and becomes } \\
\text { compulsory after this Law was } \\
\text { released. }\end{array}$ & \\
\hline
\end{tabular}

Sources: [1], [15], [26-27].

\section{A. Accreditation Process}

A significant focus of the law is improving the quality of hospital services so that they meet minimum standards of service through the accreditation process. Thus, accreditation becomes compulsory and mandatory, and even though accreditation is difficult, hospitals must obey the law. In addition, according to this law, the accreditation process is required at least once every three years. This means that the hospital needs to manage its activities in three phases after accreditation. In the first year the hospital prepares as it responds to the Indonesian Commission on Hospital Accreditation's (KARS) recommendations; in the second year it implements the new routines in everyday practices; and in the third year it prepares for the next accreditation (of both administration and practices). 
Through this cycle, this law is highly influential on hospital routines (both administrative and medical) because hospitals want to achieve good accreditation results and provide better services. In fact, accreditation helps public hospitals to fill out forms more frequently due to the minimum standard of services requirements, even if hospitals are still learning to change their habits. As one senior manager said:

[After accreditation processes] standards are used routinely, from 'there is no standard' to 'there is standard', such as [standard for] highrisk team. 'Green hospital' and 'patient safety' are other standards for next accreditation...The most important aspect is documentation [administrative] and action [process] in the field (hospital). Good administration will help us to perform well because we have to show both process [services] and data as results of process (G1_A5).

\section{B. Performance Reporting}

There are major activitities in public hospitals can be classified as clinical and non-clinical activities [28]. Clinical activities relate to health care services and non-clinical activities involve administration and management, staff development and education programs, and evaluation and quality management [28]. These two activities have minimum standards that public hospitals should fulfil, which are set by the Indonesian government and its accreditation institution. Aside from these obligations, public hospitals have responsibilities to follow regulations on quality reporting, to measure patient satisfaction, and to ensure routines meet expected standard operating procedures and standards for minimum hospital service [29].

There is one program, Jamkesman, that influences the hospital to improve both administration and practice, such as fill out the forms regularly. One senior manager and professional explained:

[The] community health assurance (Jamkesmas) program drive staff, especially doctors, willing to fill out the clinical pathway and even slowly, [we] hope that there is [change]. Therefore, it must exist standard on operating procedure for clinical privilege and clinical pathway, such as planning on medication...If this will apply to all patients [general/health insurance], it will be better even though this is starting point toward excellent services on that clinical pathway (G1_P2).

Hospital attention to patient safety has also improved due to [1] and to central government regulations. Implication of patient safety will improve the quality of services for patients and the hospital. As one senior professional and manager said, 'There is response to obey the Law on safety for patient, staff; hospital (corporate)...will do improvement until the existence of medical privilege...toward excellence services' (G1_P2).

Improved quality and achievement of minimum standards of services can be realized by accreditation because this process drives hospitals to comply with the [1]. In 2010, Hospital P and Hospital A were enthusiastic about the accreditation process. It helped both hospitals improve both their administrative and medical routines for services, even though it made them more busy: it required extra clerical work, and better coordination with others divisions. As one manager explained:

At the beginning of accreditation, we were chaotic. After we knew what data we needed, then we coordinated with all divisions to prepare data. We will continue to use this data for the next accreditation' (G1_P1).

\section{Patient Feedback}

Most of the Indonesian public hospitals use patient feedback as a method to help in improving health services. This is an easy way for patients to communicate in their own language and for public hospitals to do continuous improvement in everyday practices and to meet government regulations, such as [1] on patients' rights of services, and [25] on measuring patients' index of satisfaction. 
Each of the four hospitals also holds regular meetings to discuss patient complaints. These meetings are called morning reports. They also meet twice a week with all divisions to communicate and solve problems. The Indonesian Joint Commission on Hospital Accreditation (IJCHA/KARS-Komite Akreditasi Rumah Sakit)/also encourage these meetings as part of the accreditation processes. This is because they can lead to patients getting better services and public hospitals improving their practices and processes. As one professional and manager explained:

Every Thursday is the medical committee meeting. We discuss current clinical case problems in the hospital and how we solved them. This includes recommendations on kinds of advanced training that staff need to attend for medical staff (doctors and nurses) in order to meet the standard competency of medical staff in providing health provision and hospital needs for innovation of new services, such as HD service. We also share information on hot clinical issues in health and transfer knowledge to others during this meeting (G1_S1).

\section{DISCUSSION}

One reason for policy interventions is to provide patients with the quality of services [16]. Even though such government regulations or policies are developed from the bottom up by accommodating hospital needs, it still needs some adjustments because of differences in relation to staff characteristics, organizational establishment, and the local government's capacity. For example, the four hospitals follow government regulations to undertake their reporting but how they use such reporting, such as performance on coverage of health services for improving services, depends on the individual hospital. This is because the active role from top management, such as the director, concerns performance data that then has input into the hospital's strategy and compliance to government regulations. This drives a hospital to do better with data in improving health provision.

Ensuring patient access is one approach to improved quality of health services. Patient access to health services emphasizes "whether individuals can access health structures (facilities) and processes (services) of care which they need" [10]. The question of access is about the ease with which patients can get quality services from providers at an affordable price and in a timely manner [3]. With the national program of community health assurance (jaminan kesehatan masyarakat/jamkesmas), poor people can access all out-patient and in-patient services in the hospital free of charge because the local government will pay for the service [30].

Hospitals can also improve quality by increasing patient access to services [10], strengthening the implementation of service standards, providing sufficient facilities, undertaking continuous quality improvement, and implementing clinical governance. To ensure these activities are sustained in practice, hospitals need support tools from (top) management, such as ensuring that data is available, and that there is better coordination in demands for data from external regulators. These external regulators include the Ministry of Health, the Ministry of State Apparatus and Bureaucractic Reforms, the Indonesian Audit Body (BPK), the City/Regency Health Department, and the Indonesian Committee on Hospital Accreditation (Komite Akreditasi Rumah Sakit/KARS).

There are government regulations on the quality of hospital services. However, they are difficult to apply due to technical problems, such as lack of competent staff and no specific technical guidance. For example, the four hospitals understand that continuous quality improvement is important in improving health provision. Hospitals use accreditation processes for improving services because [1] requires accreditation processes to measure quality services in public hospitals. Accreditation processes encourage hospitals to become more aware of the data. This is because the process of accreditation focuses on administrative documents to ensure process quality improvement [31]. This happens because the IJCHA believes that accreditation documents truly reflect routines. In fact, hospitals still face problems with data gathering to fulfil accreditation processes and to 
meet the standard minimum of services for hospital as a base from which to improve services, such as trends in services. Hence, accreditation processes need to be modified in order to accommodate administration requirements and ensuring routines by evaluating the accreditation after the accreditation process is completed.

\section{CONCLUSIONS}

Policy interventions are to provide patients with the quality of services. Through these, the Indonesian government wants to encourage hospitals to focus on compliance with the standards, on better practice of administration and evaluation, and on meeting patient expectations.

Due to changes in policy through the accreditation process, hospitals can improve the quality of services from improvement of activity, data and process of services. This is because accreditation processes encourage hospitals to become more aware of the data. This is because the process of accreditation focuses on administrative documents to ensure process quality improvement.

Given the role of hospitals in providing services to patients, clinical performance is more important than administrative performance. Indirectly, clinical performance becomes one of the methods to assess both hospital quality management of services and physicians. That is, clinical performance is a signal to the physicians and managers in the hospital of the quality of services. It is important because such data will indicate if there is something wrong with managerial services or clinical services. Thus, for future research, it needs to trace reliable data to solve the problems and to improve health provision in Indonesian hospitals. It means future research focus on data management and data use in quality improvement process.

\section{ACKNOWLEDGEMENTS}

This research took place through the University of Canberra and I owe my greatest gratitude and sincere thanks to Dr Chris Sadleir and Dr Anni Dugdale for their support and guidance. I would also like to express my appreciation to the Ministry of Research, Technology and Higher Education for the scholarship allowing me to pursue this study and to the Faculty of Economics and Business of Mulawarman University for the funding to continue this study.

\section{REFERENCES}

[1] Indonesia Law. (2009). No. 44: Hospitals. Jakarta.

[2] Ministry of Health. (2008). Keputusan Menteri Kesehatan No. 129/Menkes/SK/II/2008: Minimal standard services for hospital. Jakarta.

[3] Donabedian, A. (1980). Explorations in quality assessment and monitoring: the definition of quality and approaches to its assessment. Ann Arbor, Michigan: Health Administration Press.

[4] International Society for Quality in Health Care (ISQua). (2007) Available: http://www.isqua.org/isquaPages/Accreditation.html.

[5] Soepojo, P., Koentjoro, T., \& Utarini, A. (2002). Benchmarking of hospital accreditation system in Indonesia and Australia. Jurnal Manajemen Pelayanan Kesehatan (Indonesian: Journal of Health Services Management), 5 (2), 93-100.

[6] Ministry of Health. (2016), Indonesian health profile, Jakarta.

[7] Donabedian, A. (1966). Evaluating the quality of medical care. The Milbank Memorial Fund Quarterly, 44 (3), 166-203.

[8] Donabedian, A. (2003), An introduction to quality assurance in health care. London: Oxford University Press.

[9] Mitchell, P. H., Ferketich, S., \& Jennings, B. M. (1998). Quality health outcomes model. Health Policy, 30 (1), 43-46.

[10]Campbell, S. M., Roland, M. O., \& Buetow, S. A. (2000). Defining quality of care. Social Science and Medicine, 51, 1611-1625.

[11] Institute of Medicine (IoM). (1999). Measuring the quality of health care. Washington, DC: National Academy Press.

[12]Romano, P. S., \& Mutter, R. (2004). The evolving science of quality measurement for hospitals: implications for studies of competition and consolidation. International Journal of Health Care Finance and Economics, 4, 131-157.

[13] Santos, S. P., Belton, V., \& Howick, S. (2002). Adding value to performance measurement by using system dynamics and multicriteria analysis. International Journal of Operations and Production Management, 22 (11), 1246-1272.

[14]Deming, W. E. (1982). Quality, productivity, and competitive position. Cambridge: Massachusetts Institute of Technology, Center for Advanced Engineering Study.

[15] Indonesian Joint Commission on Hospital Accreditation. (2010). Hospital Accreditation in Indonesia. Jakarta.

[16] Sutherland, K., \& Leatherman, S. (2006). Regulation and quality improvement: a review of the evidence. London: The Health Foundation.

[17] Joint Commission International. (2010). Joint Commission International Accreditation Standards for Hospitals. Illinois: 4rd edition.

[18] Ministry of Health. (2008). Ministry of Health Regulation of Republic of Indonesia No: 741/Menkes/PER/VII/2008, Standard Minimum of Services for Health Sector at Regency/City. Jakarta.

[19] Sari, W. (2016). Indonesia and the Challenge of Improving Services in Public Hospitals via Performance Measurement. Australia, University of Canberra: PhD Thesis.

[20]Hearld, L. R., Alexander, J. A., Fraser, I., \& Jiang, H. J. (2008). Review: How do hospital organizational structure and process affect quality of care?: A critical review of research methods. Medical Care Research and Review, 65 (3), 259-299.

[21]Walter, M. (2010). Social Research Methods. New York, Oxford University Press: 2nd edition.

[22] Denzin, N. K., and Lincoln, Y. S. (2005). Handbook of qualitative research. California, Thousand Oaks: Sage Publication.

[23]Bryman, A. (2012). Social research methods. New York, Oxford University Press: 4th edition.

[24] Mabry, L. (2008). Case study in social research, The Sage Handbook of Social Research Methods. London, Sage Publications.

[25] Ministry of State Apparatus and Bureaucracy Reforms Decree. (2004). Keputusan Menteri Aparatur Negara No: KEP/25/M.PAN/2/2004 
General guidance for index of community satisfaction at services unit of government institution. Jakarta.

[26] Indonesian Government Regulation. (2006). No 8: Financial and performance reporting for government institution. Jakarta.

[27] Ministry of Internal Affairs Regulation. (2007). No. 61: Technical guidance of financial management for local general services body (Badan layanan umum daerah/BLUD). Jakarta.

[28]Joint Commission. (2007). Improving America's Hospitals: the joint commission's annual report on quality and safety. Illinois.

[29]Feldman, M. S., \& Pentland, B. T. (2003). Reconceptualizing organizational routines as a source of flexibility and change. Administrative Science Quarterly, 48, 94-118.

[30] Ministry of Health. (2010), Peraturan Menteri Kesehatan Republik Indonesia No: HK.02.02/Menkes/095/I/2010: Penyelenggaraan jaminan kesehatan. Jakarta.

[31] Sari, W. (2017). The Role of Regulations on Administrative and Practices in Improving Quality of Services in Public Organizations. Cogent Business and Management, 4:1396952. 